\title{
English Reading Comprehension Strategies Employed by the Students of First-Year English Education Program
}

\author{
Eddy Haryanto ${ }^{1}$, Amirul Mukminin ${ }^{2}$, Akhmad Habibi $^{3}$, Urip Sulistiyo ${ }^{4}$, Misbie Septi Peni ${ }^{5}$ \\ Master Program of Primary Education, Jambi University, Jambi, Indonesia ${ }^{1}$ \\ Master Program of Educational Management, Jambi, Indonesia ${ }^{2}$ \\ Faculty of Education and Teacher Training, Jambi University, Indonesia ${ }^{3,4,5}$ \\ akhmad.habibi@unja.ac.id
}

\begin{abstract}
This study was aimed to obtain deeper understanding and rich information about the reading comprehension strategies employed by the first year English education program students. The participants of this study were first year students of English education program in Jambi University who got the highest scores in the course of Reading for General Purposes (RGP) of two classes (A and B). The study involved 6 students as the participants consist of 3 students from each class. This study used qualitative design with a case study approach. In order to get the required and appropriate participants of the research, the documentary evidence which is the list of RGP scores of the two classes' students was utilized. An interview protocol which consists of 20 questions was used to obtain the data in accordance with the employment of English reading comprehension strategies. Reading strategies (cognitive and meta-cognitive) were evaluated under three headings: prereading, while-reading, and post-reading. The results of this study indicated that the common English reading comprehension strategies employed by the participants in prereading is meta-cognitive strategy: reading the topic or heading of the text, looking at the pictures, graphs, maps, and other signs, and reading some first sentences. In while-reading, cognitive strategy was commonly employed: reading for better understanding, and taking notes or underlining some important information in a text. Further, in post-reading, cognitive strategy was applied: checking or evaluating their comprehension. Suggestion and recommendation are offered to all stakeholders: higher institution students, lecturers, and other related parties.
\end{abstract}

Keywords: learning strategies, reading strategies, and Reading for General Purposes

\section{INTRODUCTION}

Learning strategies are special thoughts or behaviors that individuals use to help them comprehend, learn, or retain new information (O'Malley et al, 1985). In every aspect of life, learning strategies are needed to make learning easier and they include language learning. Language learning strategies are defined as the ways or steps employed by students to obtain the target in learning languages influencing the information in deriving, storing or employing it with the goal to achieve the students' purposes (Oxford, 1990;
Hardan, 2013). In English teaching and learning process, those strategies have an important role to get students to be competent in using English (Bidabadi \& Yamat, 2013). Furthermore, learning strategies play an important role for learners during teaching and learning process of English.

In the last decades, reading centers focused on the importance of reading strategies, or the specific heuristics, methods, or procedures applied by readers intentionally to adequately process and understand the information presented in a text (Poole, 2009). Shang (2011) stated that strategies in reading are defined as the mental operations used by the readers when they have purposefully approached a text to make a sense of what they read and gain comprehension in reading.

O'Malley et al. (1985) divided learning strategies into six types. They were: memory strategies which refer to the ways students remember what they have learned, cognitive strategies which refer to the ways students determine the limitation of knowledge, meta-cognitive strategies which refer to the ways students organize their ways in learning, compensation strategies that refer to the ways students determine the limitation of information and knowledge and compensate the limitation with other ways of problem solving, affective strategies which refer to strategies that relate to students' feelings, and social strategies which refer to the way of students in learning by involving the others.

Saricoban (2002) categorized reading strategies into two kinds, namely direct and indirect strategies. Further, direct strategy was separated into cognitive strategies where students deliver direct actions in solving the problem such as direct analysis, transformation, and synthesis of learning material, and meta-cognitive strategies where students use self-directed strategy in learning, such as planning, setting goals, and managing self-management. Meanwhile, indirect strategies are used in the communication when the speakers get problems with their interlocutor in a conversation.

Reading is a skill, which involves making sense and deriving meaning from the printed words (Linse \& Nunan, 2005). In order to do that, the readers need to comprehend what they read. Reading and comprehending foreign 
language texts is not as easy as reading and comprehending native language texts. In English study program of Jambi University, English reading is a compulsory course so that the students cannot avoid reading activities. In addition, the ability to read academic texts is considered as one of the most important skills that university students of English as a second language (ESL) and English as a foreign language (EFL) need to acquire (Tercanlioglu, 2004; Vianty, 2007). Therefore, the students need to pass some types of reading courses. This regulation requires the students to have good ability in reading English texts.

There are some related studies which have been done and published about reading comprehension strategies such as the ones conducted by O'Malley et al.(1985); Ozek and Civelek (2006); Tsai (2008); Hermida (2009); Maghsudi and Talebi (2009); Genc (2011); Shang (2011); Temur and Bahar (2011); Nordin et al. (2012). However, those studies did not particularly see the use of meta-cognitive (refers to the ways students organize their ways in learning) and cognitive strategies (refers to the ways students determine the limitation of knowledge) in three stages of reading: prereading, while-reading, and post-reading. In different ways, the present study was carried out to obtain deeper understanding and rich information about the reading comprehension strategies especially on the mere use of metacognitive and cognitive strategies in Indonesian higher school context.

For academic year 2015/2016, Jambi University used $K K N I$. In this curriculum, reading course is one of skill courses. It is divided into three levels; Reading for General Purposes, which is learned by the students in the first semester, Reading for Professional Context in the second semester, and Reading for Academic Purposes in the third semester. In this research, first year students of English education study program were involved. Hence, the participants of this research have passed RGP course. Moreover, the first year EFL students are new comers who got a new milieu and new learning process. They have to face many challenges during their transition from learning in secondary school to learning in post-secondary environments (Parr \& Woloshyn, 2013). For the first time, they experienced a culture shock and were not accustomed to the atmosphere of university. They got many courses, including RGP course. Reading in universities is not the same as reading in senior high schools. It therefore takes time for new students to adapt. One of the many ways is through reading comprehension strategies, as the use of various reading strategies had been proven reliable to improve students' reading comprehension (Brown, 1994; Tercanlioglu, 2004).

\section{METHOD}

This research used a qualitative design with a case study approach to investigate reading comprehension strategies employed by the first year English education program students in Indonesia. A case study research is a research through which the researcher comprehensively explores a program, an event, an activity, a process, or one or more individuals (Creswell, 2007).The research site of this study was Jambi University, a university located in Jambi, a province in the southern of Sumatra Island, Indonesia. This university is well known as a newly developing research university and one of its programs is English study program. This research was intended for English education study program students.

Purposive sampling was considered as the most suitable sampling procedure in this case study research. It means that the sample was chosen by the researchers with some criteria of students who passed the RGP course and got the highest scores (scores of A). In finding the participants, suitable with those criteria, the researcher asked the lecturer who taught the course to get the list of the scores of the students. Afterwards, the researcher chose the students who got the highest scores in two classes. In the research principle ethics, respect for persons requires a commitment to ensuring the autonomy of research participants where autonomy may be diminished and to protect people from exploitation of their vulnerability. The dignity of all research participants must be respected. Adherence to this principle ensures that people will not be used simply as a means to achieve research objectives (Patton, 1990; Creswell, 2007). In this research, names of the participants are pseudonym in order to keep the participants confidential and make them feel comfortable as the participants.

Table 1. Group of Participants

\begin{tabular}{lllll}
\hline No & Initial & Age & $\begin{array}{l}\text { Score } \\
\text { Reading }\end{array}$ & of \\
\hline 1 & R1 & 18 & 95 \\
2 & R2 & 18 & 90 \\
3 & R3 & 19 & 88 \\
4 & M1 & 18 & 88 \\
5 & M2 & 19 & 85 \\
6 & M3 & 19 & 80 & \\
\hline
\end{tabular}

There were two instruments used in this research. The first instrument was documentary evidence in the form of list of RGP scores and the second was interview. One of the ways to collect the data is to interview research participants. An interview is a data-collection method which an interviewer (the researcher or someone working for the researcher) asks questions to an interviewee (the research participants) (Johnson \& Christensen, 2008). A structured interview was conducted to obtain the data and analyzed by transcribing, coding and elaborating the data.

In qualitative research, the trustworthiness features consist of authenticity and credibility. Validity does not carry the same connotation as it does in quantitative research, neither is a companion of reliability. Validity is seen as a strong factor and it is used to determine whether the findings are accurate from the stand point of the researcher, the participants, or the readers of an account (Creswell, 1994). In pursuit of the trustworthiness of the research, the researcher did triangulation, member checking, and reflexivity. 
Triangulation is a method used by qualitative researchers to check and establish validity in their studies by analyzing a research question from multiple perspectives (Patton, 1990; Creswell, 2007).

\section{RESULT DISCUSSION}

This research analyzed the common English reading comprehension strategies employed by the first year English education program students in pre-reading, while-reading, and post-reading. The strategies observed in this research were cognitive and meta-cognitive strategies. According to O'Malley et al. (1985) Cognitive Strategies refer to the ways students determine the limitation of knowledge. Meanwhile, Metacognitive Strategies refer to the ways students organize their ways in learning. The interview results were analyzed in each stage: pre-reading, while-reading, and post-reading.

According to Saricoban (2002) Pre-reading stage consists of the activities which readers do in constructing meaning from context, and these activities assist students to activate what they know about a topic and guess what they will read. The result of the interview is shown in Table 2 and elaborated afterwards.

Table2. The result of the interview of pre-reading

\begin{tabular}{lll}
\hline Strategy & $\begin{array}{l}\text { Activities } \\
\text { (Participants) }\end{array}$ & Excerpts of the interview \\
\hline Cognitive & $\begin{array}{l}\text { Use prior } \\
\text { knowledge to } \\
\text { understand a text } \\
\text { (1) }\end{array}$ & $\begin{array}{l}\text { Umm, for that I just look at } \\
\text { the theme and then look at } \\
\text { similar like famous words it } \\
\text { makes me, to help me, to } \\
\text { make me understanding what } \\
\text { the text tells about. }\end{array}$
\end{tabular}

Meta- $\quad$ Read the topic or I also read the topic. Umm, I cognitive heading of the text can't understand a text (6) without reading the topic and certainly it saves time.

Look at the pictures, graphs, maps, diagrams, I will look at the title from and other signs (6) the title I will guess what the text about and then if there is [are] pictures, map, graphs and other signs, I will look at [them] to guess what text about.

Preview the text I often preview the text before reading it (5) before I completely read the text. It is so helpful to give me a little description and comprehension about the text.

Read the first sentence of the paragraphs (5)

I just read the main sentence of the paragraph and then look at like guessing the
In pre-reading activity, only did one participant say that he used prior knowledge to understand the text that he wanted to read; this activity is an activity which is part of cognitive strategy. He revealed his statement as follows.

Umm, for that I just look at the theme and then look at similar like famous words it makes me, to help me, to make me understanding what the text tells about. (RI)

On the other hand, most participants said that they used metacognitive strategies in pre-reading activities. The metacognitive strategy that they meant includes some activities: reading the topic or heading of the text; looking at the pictures, graphs, maps, diagrams, and other signs; previewing the text before reading it; and reading the first sentence of the paragraphs.

All participants said that they read the topic or heading of the text when they were in pre-reading activities. One of their opinions is provided below.

I also read the topic. Umm, I can't understand a text without reading the topic and certainly it saves time. (R3)

Furthermore, they all also informed that they looked at the pictures, graphs, maps, diagrams, and other signs to understand more about the text they are going to read. M3 said,

I will look at the title from the title I will guess what the text about and then if there is [are] pictures, map, graphs and other signs, I will look at [them] to guess what text about. (M3)

In addition, five of six participants revealed that they previewed the text before reading it and read the first sentence of the paragraphs in pre-reading, which both are forms of meta-cognitive strategy. Those activities are revealed from two participants' interview excerpts as follows.

I often preview the text before I completely read the text. It is so helpful to give me a little description and comprehension about the text. (M1)

I just read the main sentence of the paragraph and then look at like guessing the meaning from the context not all the context such as read. (M2) meaning from the context not all the context such as read.
While-reading is the stage when the readers build their understanding of the text and become engaged in reading process by using the appropriate strategies and thinking more about the strategies. 
Table 3 . The result of the interview in while-reading

\begin{tabular}{lll}
\hline Strategy & $\begin{array}{l}\text { Activity } \\
\text { (participant) }\end{array}$ & Excerpt \\
\hline Cognitive & $\begin{array}{l}\text { Pay attention to the } \\
\text { parts of sentences } \\
\text { (5) }\end{array}$ & $\begin{array}{l}\text { What the subject and } \\
\text { object of the text, what } \\
\text { the text tells about maybe } \\
\text { like question anything } \\
\text { there we have to know. }\end{array}$
\end{tabular}

Guess the meaning of unknown words (5)

Of course, I will guess the meaning from the context. I will read first sentence.

Take notes, Read all of the text make highlight important notes (5)

notes sometimes or underline.

Re-read for better understanding (5)

Usually I just read again twice or third.

Meta- Link information

cognitive among sentences(6)

It is important to know how to link the sentences from sentence to sentence.

Read the whole text quickly to understand the main idea (6)

Try to figure out the main idea of each paragraph (6)

Guess meaning of a word or phrase using clues (6) text (6)

I think I just gonna take specific information from the paragraph.

I think from main idea I will get what the text about I will read the whole paragraph I will guess what's text about main idea.

Read first sentence, looked at supporting sentence, look at the important information. Not read the whole it's wasting time.

Ever, sometimes the guessing was right and sometimes was wrong.

confirm predictions $I$ will check it again to (5) make sure my prediction. and re-read for better understanding. These activities are included as cognitive strategies. The facts are revealed from some excerpts of the interview below.

What the subject and object of the text, what the text tells about maybe like question anything there we have to know. (Rl)

Of course, I will guess the meaning from the context. I will read first sentence. $(R 3)$

Read all of the text make notes sometimes or underline. (MI)

Usually I just read again twice or third. (M3)

However, there are more activities related to metacognitive strategy: linking information among sentences, reading the whole text quickly to understand the main idea, trying to figure out the main idea of each paragraph, guessing meaning of a word or phrase using clues, predicting or guessing the text, and confirming predictions. Most students do these activities while they are assigned to read a text(s). The related excerpts of the interview are provided below.

It is important to know how to link the sentences from sentence to sentence. $(R 2)$

I think I just gonna take specific information from the paragraph. (M3)

I think from main idea I will get what the text about I will read the whole paragraph I will guess what's text about main idea. (Rl)

Read first sentence, looked at supporting sentence, look at the important information. Not read the whole it's wasting time. (M2)

Ever, sometimes the guessing was right and sometimes was wrong. (R3)

I will check it again to make sure my prediction. (M1)

Post-reading activity is a stage where the readers should summarize major ideas and evaluate their readings, as the validation if the readers have a deeper understanding of the text (Blachowicz \& Ogle, 2001 as cited in Nordin et al, 2012).

Most students (five participants) said that they paid attention to the parts of sentences, guessed the meaning of unknown words, took notes or highlighted important notes, 


\section{CONCLUSION}

Table 4. The result of the interview in post-reading

\begin{tabular}{lll}
\hline Strategy & $\begin{array}{l}\text { Activities } \\
\text { (participant) }\end{array}$ & Excerpt of the interview \\
\hline Cognitive & $\begin{array}{l}\text { Make } \\
\text { inferences after } \\
\text { finishing a } \\
\text { reading text (6) }\end{array}$ & $\begin{array}{l}\text { I will make conclusion from } \\
\text { what I get from the } \\
\text { paragraph from specific } \\
\text { information, I get. }\end{array}$ \\
& $\begin{array}{l}\text { Checker } \\
\text { evaluate the text } \\
\text { (5) }\end{array}$ & $\begin{array}{l}\text { Yeaah, ee I think I just gonna } \\
\text { read } \text { what I get from text and }\end{array}$ \\
& $\begin{array}{l}\text { Go back to read my friend. } \\
\text { the details of } \\
\text { the text (6) }\end{array}$ & $\begin{array}{l}\text { ohh well sometimes I do that } \\
\text { when there is a text because I } \\
\text { use to do that I don't know } \\
\text { reading and now I learn } \\
\text { about reading activities it is } \\
\text { useless just understand the } \\
\text { we need to go back but not to } \\
\text { the whole a yeah just remind. }\end{array}$ \\
&
\end{tabular}

In this part, only cognitive strategy is used by the participants to comprehend English texts. The cognitive strategy includes: making inferences after finishing reading the text, checking or evaluating the text, and going back to read the details of the text.

In making inferences after finishing and going back to read the details, all interviewees informed that they did it in comprehending an English reading text. Two of them reported their thought in the interview as follows.

I will make conclusion from what I get from the paragraph from specific information I get. (M3)

Oh well sometimes I do that when there is a text because I use to do that I don't know reading and now I learn about reading activities it is useless just understand the we need to go back but not to the whole a yeah just remind. (M1)

In addition, most participants informed the researcher that they checked or evaluated the text in the post reading activity. They informed the researchers in the session of the interview as follows.

Yeah, ee I think I just gonna read what I get from text and share with my friend. $(R 2)$

We search clue that exist in the question. For instance, the question asked about year so we search in the text in the year part of course the answer was there. (M3)
The purpose of this research was to investigate the common English reading comprehension strategies employed by the first year English education program students in pre-reading, while-reading, and post-reading. The strategies observed in this research were particularly cognitive and meta-cognitive strategies. The result of this research indicated that, in prereading activities the first year English education program students as the participants of this research commonly used meta-cognitive strategy.

On the other hand, the common English reading comprehension strategy employed by the participants was cognitive strategy in while-reading. In post-reading, the common English comprehension strategy was cognitive strategy. This finding was consistent with the previous studies related to English reading comprehension strategy by O'Malley et al. (1985); Ozek and Civelek, (2006); Tsai, (2008); Hermida, (2009); Maghsudi and Talebi (2009); Shang (2011); Genc (2011); Temur and Bahar (2011); and Nordin et al. (2012).

Suggestions and recommendations are offered to all stakeholders; higher institution students, lecturers, researchers and other related parties for the betterment of English reading course. The appropriate teaching strategies in learning reading are proposed for the lecturers and teachers. For students, it is hoped that they are able to adapt with good strategies when they attend a reading courses. In additions, it is suggested for the authorities to implement appropriate policy and regulation as well as implement established curricula for reading courses.

\section{REFERENCES}

Bidabadi, F. S., \& Yamat, H. (2011). The relationship between listening strategies used by Iranian EFL freshman university students and their listening proficiency levels. English language teaching, 4(1), 26-32.

Brown. D. (1994). Teaching by principles an interactive approach to language pedagogy (2nd ed.). San Francisco, California: Longman

Creswell, J. (2007). Qualitative inquiry and research design: Choosing among five traditions. Thousand Oaks, CA: Sage Publications, Inc.

Genc, H. (2011). Paper and screen: Reading strategies used by low-proficient EFL learners. Sino-US English Teaching, 8(10), 648-658.

Hardan. (2013). Language learning strategies: A general overview. Social \& Behavioural Sciences. 12(194), 1712-1726.

Hermida, J. (2009). The importance of teaching academic reading skills in first-year university courses. The International Journal of Research and Review, 3, 20-30. 
Johnson, B., \& Crhistensen, L. B. C. (2008). Educational research: Quantitative, qualitative, and mixed research (3rd ed.). Boston: Sage Publications.

Linse, C., \& Nunan, D. (2005). Practical English language teaching: Young learners. London: McGraw-Hill.

Maghsudi, M., \& Talebi, H. (2009). The impact of lingualuity on the cognitive and metacognitive reading strategies awareness and reading comprehension ability. J Soc Sci, 18(2), 119-126.

Nordin, M. N., Rashid, M. S., Zubir, S. S. I. S., \& Sadjirin, R. (2012). Differences in reading strategies: How ESL learners really read. Procedia - Social and Behavioral Sciences, 90, 468-477.

O'Malley, J., Chamot, A., Stewner-Manzanares, G., Russo, R., \& Kupper, L. (1985). Learning strategy applications with students of English as a second language. TESOL Quarterly, 19, 557-584.

Oxford, R.L., (1990). Language learning strategies: What every teacher should know. Boston: Heinle \& Heinle.

Ozek, Y., \& Civelek, M. (2006). A study on the use of cognitive reading strategies by ELT students. The Asian EFL Journal, 14, 1-26.

Parr, C., \& Woloshyn, V. (2013). Reading comprehension strategies in a first year course: An instructor's selfstudy. The Canadian Journal for the Scholarship of Teaching and Learning, 4(2), 1-12.

Patton, M. (1990). Qualitative evaluation and research methods. Beverly Hills, CA: Sage.

Poole, A. (2009). The reading strategies used by male and female of Colombian university students. PROFILE Journal, 11, 29-40.

Shang, F. H. (2011). Exploring the relationship between EFL proficiency level and reading strategy use. Centre for Promoting Ideas, 1(3), 18-27.

Saricoban, A. (2002). Reading strategies of successful readers through the three phase approach. The Reading Matrix, 2(3), 1-16.

Temur, T., \& Bahar, O. (2011). Metacognitive awareness of reading strategies of Turkish learners who learn English as a foreign language. European Journal of Education Studies, 3(2), 421-427.

Tercanlioglu, L (2004). Postgraduate students' use of reading strategies in L1 and ESL contexts: Link to success. International Educational Journal, 5(4), 562-570.

Tsai, C. C. (2008). English reading comprehension strategies employed by two elderly EFL readers. Journal of Nan Kai, 5(2), 7-12.

Vianty, M. (2007). The comparison of students' use of metacognitive reading strategies between reading in Bahasa Indonesia and in English. International Education Journal, 8(12), 449-460. 